\title{
Prediction of ${ }^{99 \mathrm{~m}}$ Tc-Biguanide Complex Structures and Their Interactions with Biological Molecules by Molecular Mechanics Calculations
}

\author{
M. Neves ${ }^{1}$ and R. Fausto ${ }^{2}$ \\ ${ }^{1}$ DEPARTAMENTO DE QUÍMICA, INSTITUTO TECNOLÓGICO E NUCLEAR, P-2685 SACAVÉM, PORTUGAL; AND ${ }^{2}$ DEPARTAMENTO \\ DE QUÍMICA, FACULDADE DE CIÉNCIAS E TECNOLOGIA, UNIVERSIDADE DE COIMBRA, P-3049 COIMBRA, PORTUGAL
}

\begin{abstract}
The structures of some Tc-biguanide complexes are predicted by molecular mechanics calculations. In addition, simulations of molecular interactions between the predicted equilibrium structures with water molecules or peptide chains are correlated with experimental data of partition coefficients and percentage of human protein binding, evaluated for the analogous ${ }^{99 \mathrm{~m}} \mathrm{Tc}$-biguanide complexes. These results suggest the value of computer-assisted design of new Tc-radiopharmaceuticals, and in particularly, stress the great interest of using molecular modelling to predict molecular properties that can be successfully correlated with results obtained by in vitro studies. NUCL MED BIOL 26;1:85-89, 1999. ( 1998 Elsevier Science Inc.
\end{abstract}

KEY WORDS. Computational chemistry, Molecular modelling, ${ }^{99 \mathrm{~m}} \mathrm{Tc}$-biguanide complexes

\section{INTRODUCTION}

Computer-assisted molecular design has become a key component of research on the relationship between molecular structure and function of biological systems. Computer modelling allows the generation and evaluation of associated physicochemical properties of molecular structures, which by simulation of intermolecular interactions, could recognize biological molecules through potential binding sites and lead to the understanding and explanation of biological phenomena.

This research area has been developed for largely on the search for new drugs in the pharmaceutical industry. However, its application is still relatively uncommon in the field of metal-based radiopharmaceuticals mainly due to the difficulty in the determination of reliable force field parameters for transition metal ions ( 1 , 5). Computational chemistry methodologies could be useful in predicting molecular structures of $\mathrm{T}_{\mathrm{c}}$-complexes, which are not readily determined experimentally, such as ${ }^{99 \mathrm{~m}} \mathrm{Tc}$-complexes at carrier-free levels $\left(10^{-6}-10^{-8} \mathrm{M}\right)$ in which inorganic classic analytical techniques are not easy to apply and the corresponding ${ }^{99} \mathrm{Tc}$ chemistry is complex. Each ${ }^{99 \mathrm{~m}} \mathrm{Tc}$-complex has its own specific properties such as electron donor/acceptor, lipophilicity-hydrophilicity balance, redox potential, $\mathrm{pK}$, chirality, and isomerism. These specific properties are the key to molecular recognition by biological molecules. Simulation of molecular interactions between the predicted Tc-complexes and biological molecules is expected to give information at a molecular level, to the specific binding involving these species.

In this paper, the computer-generated optimized geometries of the oxo neutral complexes $\left[\mathrm{TcOL}_{2}(\mathrm{OH})\right]$ are reported, where $\mathrm{L}$ is the monoanionic form of biguanide $\left[\mathrm{H}_{2} \mathrm{NC}(=\mathrm{NH}) \mathrm{NHC}(=\mathrm{NH}) \mathrm{NH}_{2}\right]$ (Big) or the N1-substituted dimethyl (DMBig), phenyl (PBig), and phenethyl (PEBig) biguanides, and calculations are undertaken by

Address correspondence to: Dr. M. Neves, Departamento de Química, Instituto Tecnológico e Nuclear, Estrada Nacional 10, 2685-Sacavém, Portugal; e-mail: mneves@itn1.itn.pt.

Received 3 January 1998.

Accepted 30 May 1998. molecular mechanics using the PCMODEL program (8) and the MMX force field (4). The reliability of the approach used in this study was first checked by detailed comparison between theoretically predicted geometrical parameters (atomic distances, valence, and dihedral angles) and the corresponding experimental values obtained by X-ray crystallography for the analogous cationic complex $\left[\mathrm{TcO}(\mathrm{DMBig})_{2}\right]^{+}(6)$. In addition to the structural predictions, the computational method used also permits a detailed evaluation of the main intermolecular interactions between the Tc-complexes and simple molecules, such as water or small peptide chains. Correlations are found between interaction energies and surface areas of the low energy aggregate species and the results of in vitro studies, as partition coefficients and percentage of human protein binding of the ${ }^{99 \mathrm{~m}} \mathrm{Tc}$-biguanide complexes.

\section{MATERIALS AND METHODS Chemistry}

The synthesis, radiochemical characterization, and the determination of partition coefficients, ionic charge, and percentage of human protein binding of the oxo neutral ${ }^{99 \mathrm{~m}} \mathrm{Tc}$-biguanide complexes were performed as described elsewhere (7). The formulation of $T_{c}(V)$ oxo biguanide complexes are supported by elemental analyses, infrared (IR) and nuclear magnetic resonance (NMR) spectra, conductivity measurements, and the X-ray crystal structures. A complete discussion on the synthesis and characterization of $\mathrm{Tc}_{\mathrm{c}}(\mathrm{V})$ and $\operatorname{Re}(\mathrm{V})$ dicationic, monocationic, and neutral biguanide complexes will be reported elsewhere (6).

\section{Molecular Mechanics}

The calculations were undertaken with the PCMODEL program (version 3.0) in a 486DX4-100 PC. PCMODEL is a simple interactive molecular modelling program that can handle up to 296 total atoms. The MMX force field is an extension of Allinger's MM2 force field, which besides performing conventional molecular mechanics calculations on the molecular $\sigma$-system, undertakes a simultaneous $\pi$-system semi-empirical valence electron self-consis- 
TABLE 1. Relevant Geometrical Parameters of $\left[\mathrm{TcO}(\mathrm{DMBig})_{2}\right]^{+}$

\begin{tabular}{lcc}
\hline & PCModel/MMX & X-ray $^{\mathbf{a}}$ \\
\hline Bond distance $(\AA)$ & 1.68 & \\
Tc $=\mathrm{O}$ & $1.97-2.01$ & 1.65 \\
Tc-N & $1.37-147$ & $1.32-1.47$ \\
N-C & & \\
Valence angles $\left({ }^{\circ}\right)$ & $96.9-116.3$ & $106.4-112.7$ \\
O $=$ Tc-N & $84.8-151.1$ & $82.9-145.2$ \\
N-Tc-N & $128.1-132.1$ & $127.5-129.4$ \\
Tc-N-C & $118.8-128.7$ & $115.5-123.1$ \\
C-N-C & $118.1-122.0$ & $116.2-126.8$ \\
N-C-N & & \\
Dihedral angles $\left({ }^{\circ}\right)$ & $177.3 ; 174.8$ & $175.8 ; 171.4$ \\
Tc-N-C-N- $\left(\mathrm{CH}_{3}\right)_{2}$ & $175.0 ; 178.1$ & $172.9 ; 177.3$ \\
Tc-N-C-NH & & \\
\hline
\end{tabular}

${ }^{\text {a }}$ From reference 6

tent field calculation. This approach enables us to improve considerably both the qualitative and quantitative description of systems having delocalized $\pi$-electrons, such as the ligands in this study. General parameters for technetium are available in this force field, where the metal covalent radius is taken to be $135.5 \mathrm{pm}$ (4).

To check the reliability of the PCMODEL/MMX calculations for the systems under analysis, a minimized structure of the analogous cationic Tc oxo dimethylbiguanide complex $\left[\mathrm{TcO}(\mathrm{DMBig})_{2}\right]^{+}$was first generated and compared with available experimental structural data (6). From the results presented in Table 1, it can be concluded that a good general agreement between the calculated and experimental structures could be achieved. The calculations were able to predict properly dihedral angles, worth noting because it is well known that these calculations are in general difficult to reproduce by molecular mechanics $(2,3)$. The calculations also agree with the experimental data showing that the $T_{c}(V)$ ion lies slightly above the plane formed by the two ligands (Fig. 1) and closes a pseudoaromatic ring, due to extensive $\pi$ electron delocalization along the N-C-N skeleton.

The structures of the neutral oxo Tc-complexes, $\left[\mathrm{TcO}(\mathrm{Big})_{2}(\mathrm{OH})\right],\left[\mathrm{TcO}(\mathrm{DMBig})_{2}(\mathrm{OH})\right],\left[\mathrm{TcO}(\mathrm{PBig})_{2}(\mathrm{OH})\right]$, and $\left[\mathrm{TcO}(\mathrm{PEBig})_{2}(\mathrm{OH})\right]$, were analyzed by similar calculations and their minimum energy structures generated. Finally, the intermolecular interactions between each one of the structures and water (or peptide chain) molecules were evaluated by optimizing the structures for each Tc-complex/water molecule or Tc-complex// peptide chain aggregate and then calculating a series of relevant structure-related properties [such as polar, apolar, and total surface areas, Van der Waals interaction energies (VDW), and dipole- dipole or charge-charge (DD/QQ) interactions] that, together with the same properties obtained for the individual components of the aggregates, can be correlated with the degree of interaction between these species within the aggregates. In these calculations, the program built-in routine for automatic generation of random starting molecular configurations was used, the whole proccess being systematically checked by inspection of relative energies of the final structures obtained. This method enabled us to undertake an extensive analysis of specific intermolecular interactions between the Tc-complexes and the water (peptide) molecules. In particular, in the case of the interactions with water, because the number of water molecules considered was successively increased, the methodology adopted here enabled us to find the global minimum in the potential energy surface resulting from the successive individual interactions under analysis, and, consequently, to rule out less favourable solvation sites.

\section{RESULTS AND DISCUSSION Geometries}

The optimized geometries of the proposed structures of Tc-biguanide complexes, $\left[\mathrm{TcO}(\mathrm{Big})_{2}(\mathrm{OH})\right], \quad\left[\mathrm{TcO}(\mathrm{DMBig})_{2}(\mathrm{OH})\right]$, $\left[\mathrm{TcO}(\mathrm{PBig})_{2}(\mathrm{OH})\right]$, and $\left[\mathrm{TcO}(\mathrm{PEBig})_{2}(\mathrm{OH})\right]$ (Fig. 2), and the values of the theoretically predicted parameters (bond distances, valence, and dihedral angles) are shown in Table 2 . In all complexes studied, the ligand molecules were found to be quasiplanar, with the C-N-C-N(R) torsion angles, $\left[\mathrm{R}=\mathrm{H}_{2},\left(\mathrm{CH}_{3}\right) 2, \mathrm{HPh}\right.$, $\mathrm{HCH}_{2} \mathrm{CH}_{2} \mathrm{Ph}$ ] varying from 169.7 to $177.5^{\circ}$. The ligand substitution effect is more relevant in the case of the phenyl and phenethyl derivatives, where the torsion angle $\mathrm{O}=\mathrm{Tc}-\mathrm{O}-\mathrm{H}$ was 143.5 and $148.2^{\circ}$, respectively, whereas in the case of nonsubstituted and dimethyl-substituted complexes this angle was 178.3 and $177.3^{\circ}$. The deviation from planarity observed in these complexes having ligands bearing a phenyl group, can be explained considering that the presence of the aromatic rings increases the overall steric hindrance considerably, thus forcing the axial ligands to assume the observed nonplanar geometry. In the case of the phenethyl derivative this effect is less pronounced, because the presence of the ethylenic chains leads to reduce steric contacts.

\section{Molecular Interactions}

Simulations of molecular interactions between water molecules and $\left[\mathrm{TcO}(\mathrm{Big})_{2}(\mathrm{OH})\right],\left[\mathrm{TcO}(\mathrm{DMBig})_{2}(\mathrm{OH})\right],\left[\mathrm{TcO}(\mathrm{PBig})_{2}(\mathrm{OH})\right]$, and $\left[\mathrm{TcO}(\mathrm{PEBig})_{2}(\mathrm{OH})\right]$ suggest the attachment of two water molecules to the complexes, by means of hydrogen bond formation between the nitrogen atoms of the guanidine imino groups and hydrogen atoms of the water molecules, as shown in Figure 3 for the specific case of $\left[\mathrm{TcO}(\mathrm{Big})_{2}(\mathrm{OH})\right]$. Additional water molecules stay close to
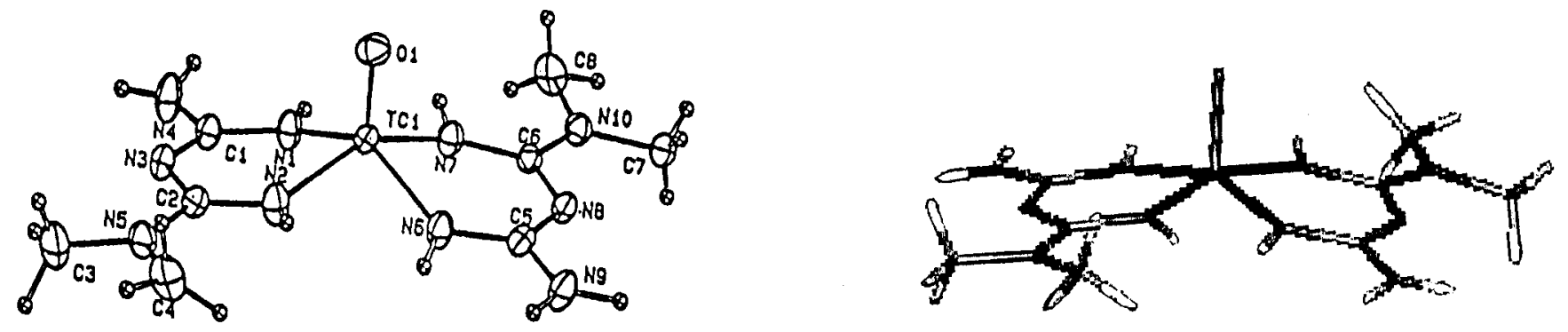

FIG. 1. X-ray structure and minimized geometry of $\left[\mathrm{TcO}(\mathrm{DMBig})_{2}\right]^{+}($stick model $)$. 
A

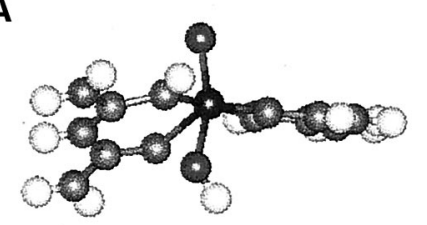

C

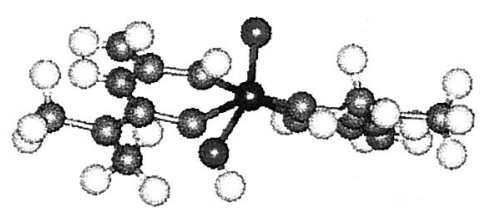

B

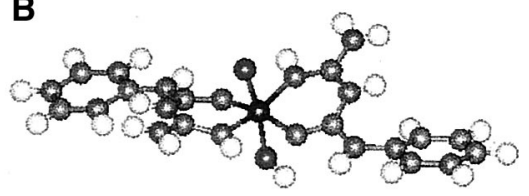

D

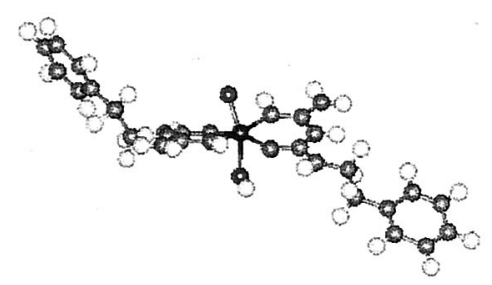

FIG. 2. Ball and stick model of minimized geometries of $(\mathrm{A})\left[\mathrm{TcO}(\mathrm{Big})_{2}(\mathrm{OH})\right],(\mathrm{B})\left[\mathrm{TcO}(\mathrm{DMBig})_{2^{-}}\right.$ $(\mathrm{OH})],(\mathrm{C})\left[\mathrm{TcO}(\mathrm{PBig})_{2}(\mathrm{OH})\right]$, and (D) [TcO. $\left.(\mathrm{PEBig})_{2}(\mathrm{OH})\right]$ the Tc aggregate environment but no more hydrogen bond formation was predicted.

The relative changes in polar surface areas $(\Delta \mathrm{SA})$ for each molecular aggregate (Tc-complex and two water molecules), relative to the sum of the polar surface areas of the individual components, may be used as a measured of the relative stability of the various aggregates (or the relative water affinity to the complex). A greater water affinity would correspond to a greater surface area reduction and, consequently, to a greater $\Delta \mathrm{SA}$ value. In addition, the relative values of $\triangle \mathrm{DD} / \mathrm{QQ}=\mathrm{DD} / \mathrm{QQ}$ (aggregate) $\Sigma \mathrm{DD} / \mathrm{QQ}$ (individual components), where DD/QQ corresponds to all Coulomb-type interaction terms in the potential energy function of each species, and may be correlated with the partition coeffi- cients experimentally evaluated for each complex. In fact, the minimum $\Delta \mathrm{DD} / \mathrm{QQ}$ value $\left(-33.15 \mathrm{kcal} \cdot \mathrm{mol}^{-1}\right)$ corresponds to the more hydrophilic Tc-complex, and the maximum $\Delta \mathrm{DD} / \mathrm{QQ}$ value $\left(+0.81 \mathrm{kcal} \cdot \mathrm{mol}^{-1}\right)$ to the less hydrophilic (or more lipophilic), which means that the electrostatic interaction energies could also be related to water affinity along the same series of Tc-complexes (Table 3). The observed correlations of relative water affinity with both, $\triangle \mathrm{SA}$ and $\triangle \mathrm{DD} / \mathrm{QQ}$, are consistent with the dipolar character of water molecules and consequently with the prevalence of Coulomb electrostatic interactions in these systems. Other structure-related parameters, such as relative changes in molecular apolar surface areas or Van der Waals interactions, are not expected to play an important role in stabilizing the aggregates,

TABLE 2. Relevant Calculated Geometrical Parameters for the Oxo ${ }^{99 m}$ Tc-Biguanide Complexes ${ }^{\text {a }}$

\begin{tabular}{|c|c|c|c|c|}
\hline & TcOBig & TcODMBig & TcOPBig & TcOPEBig \\
\hline \multicolumn{5}{|l|}{ Bone distance $(\AA)$} \\
\hline $\mathrm{T}_{\mathrm{c}}=\mathrm{O}$ & 1.72 & 1.71 & 1.73 & 1.73 \\
\hline $\mathrm{Tc}-\mathrm{OH}$ & 1.90 & 1.89 & 1.91 & 1.92 \\
\hline TC-N & $1.92-1.96$ & $1.92-1.97$ & $1.91-1.97$ & $1.92-2.04$ \\
\hline C-N & $1.38-1.41$ & $1.35-1.46$ & $1.31-1.42$ & $1.30-1.46$ \\
\hline $\mathrm{C}-\mathrm{C}$ & - & - & $1.39-1.42$ & $1.40-1.54$ \\
\hline $\mathrm{N}-\mathrm{H}$ & $0.96-0.97$ & $0.96-0.97$ & $0.96-0.98$ & $0.96-1.00$ \\
\hline $\mathrm{C}-\mathrm{H}$ & - & 1.11 & 1.10 & $1.10-1.12$ \\
\hline \multicolumn{5}{|l|}{ Valence angle $\left({ }^{\circ}\right)$} \\
\hline $\mathrm{O}=\mathrm{T} c-\mathrm{O}$ & 156.5 & 154.6 & 171.6 & 157.0 \\
\hline $\mathrm{O}=\mathrm{Tc}-\mathrm{N}$ & $91.6-111.4$ & $90.1-106.4$ & $82.0-102.8$ & $77.6-124.1$ \\
\hline $\mathrm{N}-\mathrm{Tc}-\mathrm{OH}$ & $65.9-111.7$ & $66.0-112.5$ & $83.6-103.9$ & $78.7-108.8$ \\
\hline $\mathrm{N}-\mathrm{Tc}-\mathrm{N}$ & 85.9-176.8 & $87.2-179.0$ & 83.5-167.0 & $85.1-160.8$ \\
\hline C-N-Tc & $125.8-127.4$ & $125.8-128.2$ & $118.1-127.1$ & $120.7-126.1$ \\
\hline N-C-N & $117.4-124.0$ & $118.1-124.7$ & $111.4-127.1$ & $114.1-128.7$ \\
\hline C-N-C & $124.7 ; 125.0$ & $119.2-126.2$ & 125.6-131.1 & $124.2-126.5$ \\
\hline C-C-N & - & - & $116.6-126.6$ & $109.8 ; 112.4$ \\
\hline C-C-C & - & - & $118.4-121.7$ & $118.9-130.2$ \\
\hline N-C-H & - & 109.7-111.8 & - & $105.9-109.3$ \\
\hline C-N-H & $115.6-120.8$ & $114.8-120.8$ & $114.4-121.3$ & $105.7-118.1$ \\
\hline $\mathrm{H}-\mathrm{N}-\mathrm{H}$ & $119.0-119.7$ & $119.0 ; 119.1$ & $119.0 ; 119.4$ & $118.1 ; 119.7$ \\
\hline \multicolumn{5}{|l|}{ Torsion angle $\left({ }^{\circ}\right)$} \\
\hline $\mathrm{O}=\mathrm{T}_{\mathrm{c}}-\mathrm{O}-\mathrm{H}$ & 178.3 & 177.3 & 143.5 & 148.2 \\
\hline C-N-C-NH${ }_{2}$ & $171.2-176.6$ & $169.7 ; 176.3$ & $174.2 ; 179.7$ & $173.3 ; 173.7$ \\
\hline $\mathrm{C}-\mathrm{N}-\mathrm{C}-\mathrm{N}\left(\mathrm{CH}_{3}\right)_{3}$ & - & $169.9 ; 177.5$ & - & - \\
\hline C-N-C-NH(Ph) & - & - & $169.7 ; 174.5$ & - \\
\hline C-N-C-NH(EtPh) & - & - & - & $171.6 ; 176.9$ \\
\hline
\end{tabular}

a TcOBig, TcODMBig, TcOPBig, and TcOPEBig are abbreviated notaion of $\left[\mathrm{TcO}(\mathrm{Big})_{2}(\mathrm{OH})\right]$, $\left[\mathrm{TcO}(\mathrm{DMBig})_{2}(\mathrm{OH})\right],\left\{\mathrm{TcO}(\mathrm{PBig})_{2}(\mathrm{OH})\right]$, and $\left[\mathrm{TcO}(\mathrm{PEBig})_{2}(\mathrm{OH})\right]$. 

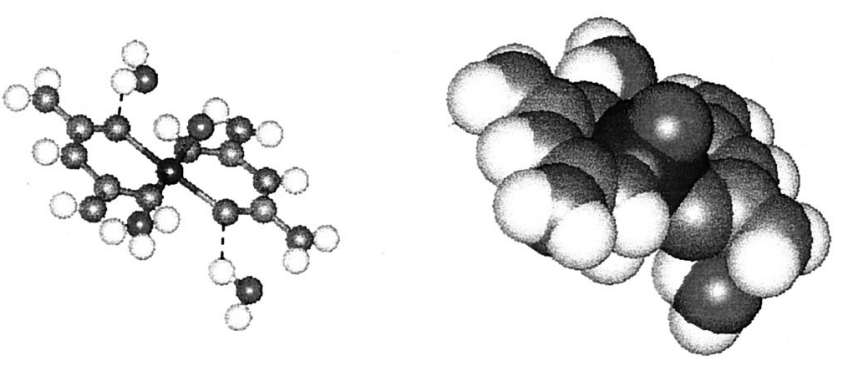

FIG. 3. Minimum energy aggregate resulting from interaction of $\left[\mathrm{TcO}(\mathrm{Big})_{2}(\mathrm{OH})\right]$ with water (ball and stick and CPK space-filling models; $\mathrm{H}$ bonds represented as dashed lines).

and were not considered. The graphical representation of partition coefficients (PC), $\Delta \mathrm{SA}$, and $\triangle \mathrm{DD} / \mathrm{QQ}$ along the series of studied Tc-complexes, gives a clear indication that calculated $\Delta \mathrm{SA}$ and $\Delta \mathrm{DD} / \mathrm{QQ}$ follow the same pattern of variation of the experimentally determined partition coefficients (Fig. 4).

Using the same methodology, the molecular interactions between the complexes, $\left[\mathrm{TcO}(\mathrm{Big})_{2}(\mathrm{OH})\right],\left[\mathrm{TcO}(\mathrm{DMBig})_{2}(\mathrm{OH})\right]$, [TcO$\left.(\mathrm{PBig})_{2}(\mathrm{OH})\right],\left[\mathrm{TcO}(\mathrm{PEBig})_{2}(\mathrm{OH})\right]$, and the simple dipeptide chain ${ }^{+} \mathrm{H}_{3} \mathrm{~N}-\mathrm{CH}_{2}-\mathrm{C}(=\mathrm{O})-\mathrm{NH}-\mathrm{CH}_{2}-\mathrm{COO}^{-}$(whose structure was previously optimized as described for all other systems here considered) were also evaluated. The optimized geometry of the dipeptide has the relevant bond distances and valence angles similar to those described in literature (in parentheses), i.e., a $\mathrm{C}=\mathrm{O}$ distance of 1.21 $\AA$ (1.24 $\AA$ ), a $\mathrm{C}(=\mathrm{O})-\mathrm{N}$ distance of $1.34 \AA$ (1.32 $\AA$ ), an N-C distance of $1.46 \AA(1.47 \AA)$, and a $\mathrm{O}=\mathrm{C}-\mathrm{N}$ angle of $125.3^{\circ}\left(125^{\circ}\right)$. As the PCMODEL can handle up a limited number of atoms, we have favoured the approach of considering multiple interactions with simple several dipeptide chains, instead of a single interaction with a large peptide.

The observed multiple interactions between the complex $\left[\mathrm{TcO}(\mathrm{Big})_{2}(\mathrm{OH})\right]$ and the dipeptide could be explained in terms of electrostatic interactions involving the different atoms of the system. Then, the hydrogen atoms of the $\mathrm{NH}_{3}{ }^{+}$group of the peptide chain (charge $+0.22 \mathrm{e}$ ) form hydrogen bonds with the electronegative nitrogen atoms of the Tc-complex (charges ranging from -0.19 to $-0.46 \mathrm{e}$ ), while the oxygen atoms of both the $\mathrm{C}=\mathrm{O}$ and $\mathrm{COO}^{-}$groups of the dipeptide (charges: $\mathrm{C}=\mathrm{O},-0.29 \mathrm{e}$;

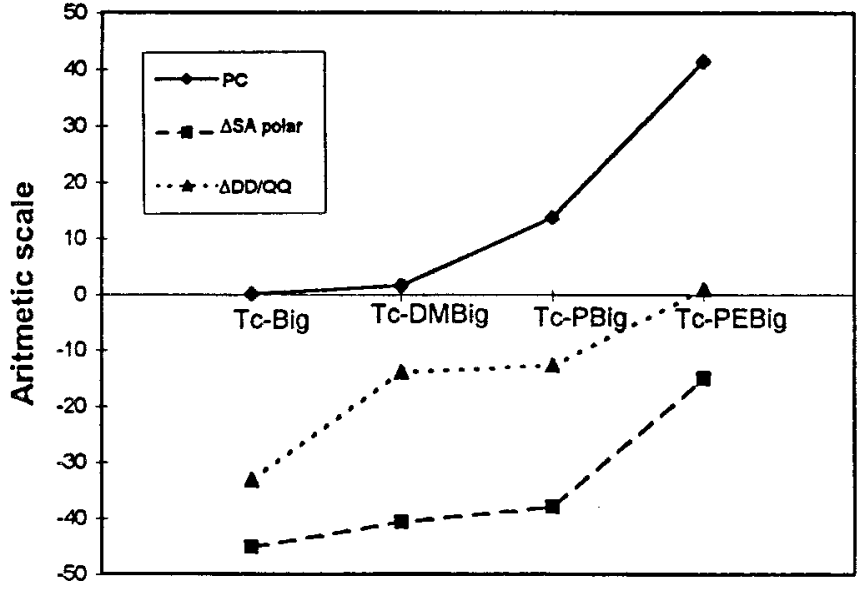

FIG. 4. Partition coefficients (PC), $\Delta \mathrm{SA}$ polar, and $\Delta \mathrm{DD} / \mathrm{QQ}$ for Tc-biguanide complexes.

$\left.\mathrm{C}(=\mathrm{O}) \mathrm{O}^{-},-0.41 \mathrm{e} ; \mathrm{C}(=\mathrm{O}) \mathrm{O}^{-},-0.79 \mathrm{e}\right)$ form hydrogen bonds with the electropositive hydrogen atom of the $\mathrm{Tc}-\mathrm{OH}$ group (charge $+0.29 \mathrm{e}$ ) and with the hydrogen atoms of the imino $(+0.22 \mathrm{e})$ and amino $(+0.15 \mathrm{e})$ groups of the biguanide ligands. The cyclization of the dipeptide can occur as shown in Figure 5, through hydrogen bond formation between the $\mathrm{COO}^{-}$and $\mathrm{C}=\mathrm{O}$ groups with imino and amino groups. The $\mathrm{COO}^{-}$group of a second dipeptide is also hydrogen bonded to the $\mathrm{Tc}-\mathrm{OH}$, imino, and amino groups. A third dipeptide is hydrogen bonded by its $\mathrm{NH}_{3}{ }^{+}$group to an imino group of the complex.

The Tc-complexes of the remaining ligands studied do not have as many amino groups acessible as $\left[\mathrm{TcO}(\mathrm{Big})_{2}(\mathrm{OH})\right]$. In addition, the effect of substitution of hydrogen atoms by the dimethyl, phenyl, and phenethyl groups on the N1 atom leads also to a reduction of the charges on all nitrogen atoms, specially those that stay closer to the substitution site. This decreasing effect can be explained considering that coordination favors electronic delocalization involving the $N$ atoms. On the other hand, the presence of nonpolar groups leads to the appearance of essentially hydrophobic surfaces that limit the extension of the attractive interactions involving polar surfaces of the complex and the peptide chains. As shown in Figure 6, in the case of the N1 dimethyl derivative, only one peptide chain interacts significantly with the complex (two hydrogen bonds, between the $\mathrm{COO}^{-}$and $\mathrm{Tc}-\mathrm{OH}$ groups and an

TABLE 3. Molecular Polar Surface Areas (SA Polar), Interaction Energies (DD/QQ), and Corresponding Changes upon Complexation with $\mathrm{H}_{2} \mathrm{O}(\Delta \mathrm{SA}$ and $\Delta \mathrm{DD} / \mathrm{QQ})$ for the Studied Oxo Tc-Biguanides ${ }^{\mathrm{a}}$

\begin{tabular}{|c|c|c|c|c|c|}
\hline & SA polar & $\Delta \mathrm{SA}$ polar & DD/QQ & $\Delta \mathrm{DD} / \mathrm{QQ}$ & Partition coeff. \\
\hline $2 \mathrm{H}_{2} \mathrm{O}$ & 76.0 & - & 0 & - & - \\
\hline TcOBig & 190.1 & - & -70.60 & - & $0.03 \pm 0.01$ \\
\hline $\mathrm{TcOBig} / 2 \mathrm{H}_{2} \mathrm{O}$ & 220.9 & -45.2 & -103.75 & -33.15 & - \\
\hline TcODMBig & 152.7 & - & -81.02 & - & $1.54 \pm 0.11$ \\
\hline $\mathrm{TcODMBig} / 2 \mathrm{H}_{2} \mathrm{O}$ & 188.0 & -40.7 & -94.87 & -13.85 & - \\
\hline TcOPBig & 169.8 & - & -97.70 & - & $13.69 \pm 0.95$ \\
\hline $\mathrm{TcOPBig} / 2 \mathrm{H}_{2} \mathrm{O}$ & 207.8 & -38.0 & -110.37 & -12.67 & - \\
\hline TcOPEBig & 147.5 & - & -97.25 & - & $41.31 \pm 1.78$ \\
\hline $\mathrm{TcOPEBig} / 2 \mathrm{H}_{2} \mathrm{O}$ & 208.5 & -15.0 & -96.44 & +0.81 & - \\
\hline
\end{tabular}

${ }^{a}$ TcOBig, TcODMBig, TcOPBig, and TcOPEBig are abbreviated notation of $\left[\mathrm{TcO}(\mathrm{Big})_{2}(\mathrm{OH})\right],\left[\mathrm{TcO}(\mathrm{DMBig})_{2}(\mathrm{OH})\right],\left[\mathrm{TcO}(\mathrm{PBig})_{2}(\mathrm{OH})\right.$, and $\left[\mathrm{TcO}(\mathrm{PEBig})_{2}(\mathrm{OH})\right]$. Water affinity expressed by partition coefficients; Polar SA in $\AA^{2}$; Interaction energies in $\mathrm{kcal} \cdot \mathrm{mol}^{-1}$. 

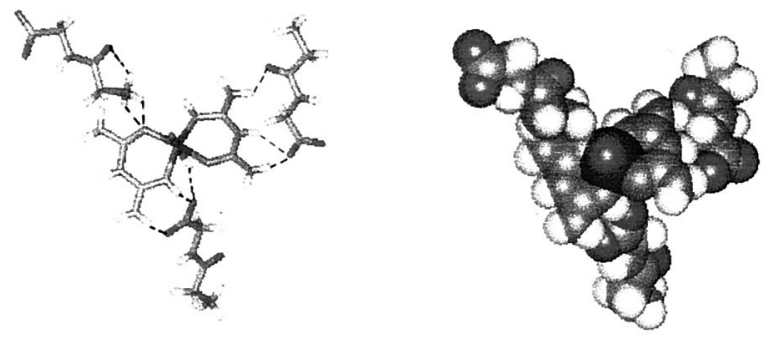

FIG. 5. Minimum energy aggregate resulting from interaction of $\left[\mathrm{TcO}(\mathrm{Big})_{2}(\mathrm{OH})\right]$ with three peptide chains (ball and stick and CPK space-filling models; $H$ bonds represented as dashed lines).

imino group are predicted). Additional peptide chains are pushed out by the essentially nonpolar dimethyl groups. In the $\left[\mathrm{TcO}(\mathrm{PBig})_{2}(\mathrm{OH})\right]$ and $\left[\mathrm{TcO}(\mathrm{PEBig})_{2}(\mathrm{OH})\right]$ complexes a similar effect is promoted by the phenyl and phenethyl groups.

The interaction of $\left[\mathrm{TcO}(\mathrm{Big})_{2}(\mathrm{OH})\right]$ with the peptide chains is clearly distinct from the processes involving the other complexes studied. The percentages of human protein binding for the various ${ }^{99 \mathrm{~m}} \mathrm{Tc}$ complexes evaluated by gel filtration are: $\left[\mathrm{TcO}(\mathrm{Big})_{2}(\mathrm{OH})\right]$ $=44.9 \pm 2.3 \% ;\left[\mathrm{TcO}(\mathrm{DMBig})_{2}(\mathrm{OH})\right]=13.4 \pm 1.1 \%$; $\left[\mathrm{TcO}(\mathrm{PBig})_{2}(\mathrm{OH})\right]=10.6 \pm 0.9 \%$; and $\left[\mathrm{TcO}(\mathrm{PEBig})_{2}(\mathrm{OH})\right]=$ $7.1 \pm 0.7 \%$. Thus, the percentage of human protein binding for $\left[{ }^{99 \mathrm{~m}} \mathrm{TcO}(\mathrm{Big})_{2}(\mathrm{OH})\right]$ is considerably higher than for all other complexes. This finding agrees with the theoretical results, which predict that $\left[\mathrm{TcO}(\mathrm{Big})_{2}(\mathrm{OH})\right]$ is considerably more efficient in establishing energetically favourable hydrogen bonds with the peptide chains. Naturally, in the case of real systems (i.e., proteins), the interactions are most likely to occur with side chain carboxyl and amino groups rather than the carboxyl and amino terminal fragments.
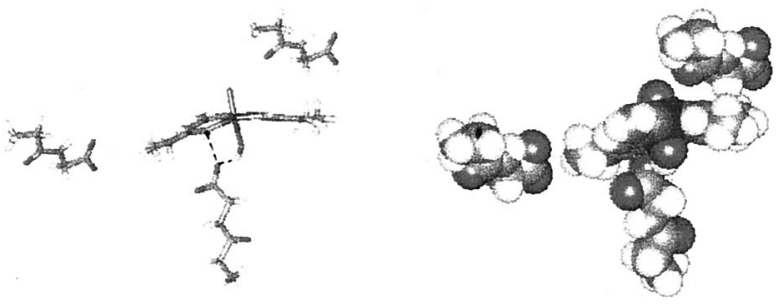

FIG. 6. Minimum energy aggregate resulting from interaction of $\left[\mathrm{TcO}(\mathrm{DMBig})_{2}(\mathrm{OH})\right]$ with three peptide chains (ball and stick and CPK space-filling models; $\mathrm{H}$ bonds represented as dashed lines).

\section{CONCLUSION}

The elucidation, at a molecular level, of the way of functioning of pharmacologically relevant systems is one of the most important challenges in biomedical research. Molecular modeling has been playing an ever-growing role in this field, and it appears nowadays as a powerful method of study, whose relevance in the specific field of radiopharmaceuticals is promising. The present study adopts this methodology to shed light on the molecular structures of pharmacologically relevant Tc-complexes of biguanides, and enabled us to establish fundamental relationships between some structure-related molecular properties and important physicochemical properties of the studied systems, such as partition coefficients and water affinity, as well as protein binding and peptide interactions. The success of this approach to study the kind of systems considered here opens good perspectives to start a series of systematic studies by this method directed both to the computer-assisted design of new Tc-radiopharmaceuticals and to the establishment of important correlations between their relevant molecular properties and results obtained from experimental in vitro studies.

This work is financially supported by the PRAXIS XXI research projects QUI/2/2.1/412/94, SAU/2/2.1/1396/95, and FEDER.

\section{References}

1. Boudreau R. J. and Mertz J. E. (1997) The prediction of the structure of technetium (V) complexes using density-functional techniques. Nucl. Med. Biol. 24, 395-398.

2. Burnet U. and Allinger N. L. (1982) Molecular Mechanics. ACS Monograph Series No. 175, American Chemical Society, Washington.

3. Fasuto R. (1996) PF1/PF2: A molecular mechanics force field for conformational studies on oxygen and sulphur compounds. Rev. Port. Quím. 3, 59.

4. Gajewski J. J. and Gilbert K. E. (1989) PCMODEL-Molecular modeling software for IBM-PC, XT, AT, PS/2 (or compatible). This force field is based on the MM2 (QCPE-395, 1977) force field of Allinger N. L., with the pi-VESCF routines taken from MMP1 (QCPE-318).

5. Hancock R. D., Reichert D. E. and Welch M. J. (1996) Molecular mechanics force fields for modeling technetium $(\mathrm{V})$ complexes. Inorg. Chem. 35, 2165-2166.

6. Marchi A., Marvelli L., Neves M., Rossi R., Bertolasi V. and Ferretti V. (1998) Biguanide complexes of technetium (V) and rhenium (V). X-ray crystal structures. To be presented at the 5 th International Symposium on Technetium in Chemistry and Nuclear Medicine, Bressanone, Bolzano, Italy, Sep. 6-9.

7. Neves M., Gano L., Ribeiro M. J., Santos A. C., Marchi A., SawasDimopolou C. and Pedroso de Lima J. J. (1999) Synthesis, Characterization and biodistribution of oxo complexes of technetium- $99 \mathrm{~m}$ with biguanide and N1-substituted ligands. Nucl. Med. Biol. 26, 79-83.

8. PCMODEL (version 3.0). Serena Software, Box 3076, Bloomington, IN 47402-3076, USA. 